\title{
BODA JÓZSEF
}

\section{A felderítés, hírszerzés, titkos információgyüjtés elvei és gyakorlata}

A titkos felderítés az ismeretek megszerzésére irányuló speciális, az érintett személy elől rejtett, szigorú szabályok közé szorított, állami szervek által végzett megismerési folyamat. A humán erökkel, a technikai és müveleti eszközökkel és módszerekkel folytatott titkos felderítés egyszerre a nemzetbiztonsági szolgálatok nélkülözhetetlen jellemzője és a bünüldöző szervek hatékony segítője. Az elmúlt évtizedek során mind a nemzetbiztonsági, mind a bünüldözési új típusú veszélyforrások jelentkeztek, amelyek megerősítették a titkos felderítés fontosságát. ${ }^{1}$

A titkos felderítés nélkülözhetetlen technikai háttere az elektronikus hírközlő hálózaton és elektronikus hírközlő eszközökkel az elektronikus hírközlési tevékenység során, illetve azzal összefüggésben keletkezett, továbbított információk, adatok kiválasztása, csatolása, technikai eszközzel történő rögzítése és megismerése. ${ }^{2}$

\section{A titkos információgyứjtés}

Büncselekmény elkövetésének megelőzésére, felderítésére, megszakítására, az elkövető kilétének megállapítására, elfogására, körözött személy felkutatására, tartózkodási helyének megállapítására, bizonyítékok megszerzésére, valamint a büntetőeljárásban részt vevők és az eljárást folytató hatóság tagjainak, az igazságszolgáltatással együttmüködő személyek védelme érdekében - a törvény keretei között - titokban végzett információgyüjtés. ${ }^{3}$

Az Információs Hivatal honlapján az alábbi meghatározást találjuk: „A titkos információgyüjtés és az ilyen módon beszerzett adatok kezelése különösen súlyos beavatkozást jelenthet a magánszférába, s természeténél fogva súlyosan korlátozhatja a személyiségi jogokat. Lényegét tekintve az adatfel-

\footnotetext{
1 Hetesy Zsolt: A titkos felderítés. PhD-értekezés, Pécsi Tudományegyetem Állam- és Jogtudományi Kar Doktori Iskola, Pécs, 2011, 2. o.

2 2003. évi C. törvény az elektronikus hírközlésröl (Eht.)

3 Rendészeti szószedet. Magyar Rendészettudományi Társaság, Budapest, 2008, 342. o.
} 
vétel, illetve adatkezelés különleges módja, amely minden fázisában (felvétel, tárolás, kiigazitás, adattovábbitás, törlés) az érintett tudta nélkül történik. "“

Egy az Igazságügyi és Rendészeti Minisztérium által 2007-ben készített törvényjavaslat részletesen magyarázza a fogalmat5:

- A titkos információgyüjtés a bünüldöző és nemzetbiztonsági szervek egyik nemzetközileg is ismert és alkalmazott, a különböző országokban lényegében hasonló tartalommal bíró eszköze.

- A titkos információgyüjtés olyan tevékenység, amelyet az érintett tudta nélkül alkalmaznak, mind a titkos információgyüjtés során alkalmazott eszközök, módszerek, mind a titkos információgyüjtést végző személyek kiléte rejtett, és az is marad.

- E tevékenység során szükségszerüen sérülnek, illetve sérülhetnek az érintett alkotmányos jogai, nevezetesen a magánlakás sérthetetlenségéhez, a magántitok, a levéltitok és a személyes adatok védelméhez füződő jogok.

- A titkos információgyüjtés speciális állami tevékenység, amely természetesen költségekkel jár, azonkívül titkossága, leplezettsége miatt szükségszerủen eltérő szabályozást igényel az adott szerv költségvetésében.

\section{A nemzetbiztonság}

- olyan - külső és belső körülmények által determinált - állapot, amelyben az adott állam zavartalanul, a teljes szuverenitás alapján gyakorolhatja funkcióit;

- adott társadalmi rendszer alapja és felépítménye, összességében az államrend egésze stabilitásának, zavartalanságának megléte;

- egy adott ország határain belül található valamennyi anyagi és humán jellegủ értékek fenyegető támadástól történő összefogott, többirányú megvédése, illetve ezek érvényesülése a határon belüli és azon kívüli tevékenységgel;

- adott nemzet azon képessége, hogy megvédje nemzeti értékeit, érdekeit minden külső és belső fenyegetés ellen;

- adott ország (nemzet) szuverenitásának, alkotmányos rendjének, biztonsági érdekeinek titkosszolgálati eszközökkel fenntartott, támogatott, külső és belső veszélyektől, fenyegetettségektől mentes állapota. ${ }^{6}$

\footnotetext{
4 http://www.mkih.hu/alkotmanyos adatkezeles.shtm

5 T/4192. számú törvényjavaslat a bünüldözési célú titkos információgyüjtésről. Budapest, 2007. október. Előadó: Takács Albert igazságügyi és rendészeti miniszter.

6 Rendészeti szószedet... i. m. 276-277. o.
} 
A Magyar Köztársaságban a Minisztertanács 26/1990. (II. 14.) MT rendeletével létrehozott, titkosszolgálati eszközök és módszerek alkalmazására feljogosított titkosszolgálat a Nemzetbiztonsági Szolgálat.

A Nemzetbiztonsági Szolgálat az 1990. évi X. tv. alapján jogosult titkosszolgálati eszközök és módszerek alkalmazására a hatáskörébe utalt büncselekmények megelőzése, megakadályozása, felderítése, bizonyítása érdekében. ${ }^{7}$

Az elöbbi fogalommagyarázatból kiderül, hogy a szakterület müvelöi, kutatói körében sincs teljesen tiszta kép a titkos információgyüjtésröl, annakfogalmi meghatározásáról.

A katonai, nemzetbiztonsági és rendvédelmi szervek felderítő, hírszerző, elhárító és titkos információgyüjtő tevékenységére vonatkozó fogalmak, eljárások és a mủveletek lényegét illetően a különböző lexikonok és jogszabályok eltérően fogalmaznak.

Következtetésként azonban levonható az a tény, hogy hazánkban átlátható módon, mindenki által hozzáférhetően, külön-külön törvény szabályozza részletesen a nemzetbiztonsági szolgálatok és az egyéb rendvédelmi szervek titkos információgyüjtő tevékenységét.

\section{Történeti visszatekintés}

A második világháború elött és az alatt a titkos információgyüjtésre hivatott szerveztek elsősorban a katonai szervezeteken belül helyezkedtek el, tevékenységüket a vezérkar és katonai törzsek irányitották, a fö cél pedig a katonai jellegü információk megszerzése volt.

Az után, hogy hazánk szovjet befolyás alá került, ez a helyzet alapvetően megváltozott, és a titkos információgyüjtés elsődleges feladatává a politikai jellegü információk megszerzése vált. A feladat végrehajtásához szükséges szervezetek kialakítása már a budapesti harcok befejezése után megkezdődött. 1945. február elején megalakult a Magyar Államrendőrség Budapesti Főkapitányság Politikai Rendészeti Osztálya. ${ }^{8}$

1946-ban a rendőri szervezetből Államvédelmi Osztály néven önállósult a politikai rendészeti terület, amelyhez már több műveleti háttértámogató részleg tartozott. 1948. szeptember 1-jei hatállyal alakult meg az Államvédelmi Hatóság (ÁVH), amely a 288.009/1948. BM rendelet értelmében, kiszélesített hatáskörrel a Belügyminisztérium közvetlen alárendeltségébe került.

7 Hadtudományi Lexikon. Magyar Hadtudományi Társaság, Budapest, 1995, 1331. o.

8 Borvendég Zsuzsanna: A levélellenőrzés megszervezése 1945-1950. Betekintő, 2011/2., 1. o. 
A hazai titkos információgyüjtő szervezetek létrehozását és müködését szovjet tanácsadók ,segítették” egészen a rendszerváltozásig.

Szovjet tanácsra a Minisztertanács 1953. július 17-i ülésén döntött az ÁVH mint önálló szerv megszüntetéséről és a Belügyminisztériummal történő összevonásáról.

A katonai hírszerzés 1953-tól ismét a vezérkar alárendeltségében müködött tovább, 2. Csoportfönökség néven. A felderítési feladatok meghatározása alapvetően a Honvédelmi Minisztérium és a vezérkar éves vagy időszakos felderítési igényei, az együttmüködő hírszerző szervek (például BM III/I. Csoportfönökség) igényei, valamint az úgynevezett „baráti” katonai felderítő (a szovjet és más, a Varsói Szerződéshez tartozó tagállamok felderítő fönökségei) igényei alapján történt. ${ }^{9}$

A szocialista országok titkos információgyüjtő szervezeteinek életében fordulatot hozott 1955, mivel 1955. március 7-15. között Moszkvában sor került az első közös állambiztonsági értekezletre.

A tárgyalásokon meghatározták azt is, hogy a magyar Belügyminisztérium ,hírszerző szerveinek” milyen fontosabb területeken kell feladatokat vállalniuk. ${ }^{10}$

A Belügyminisztériumba visszaintegrált titkosszolgálatot 1955 decemberében I. (Államvédelmi) Főcsoportfőnökség néven szervezték újjá.

Az 1957 tavaszán létrejött központi titkos információgyüjtő szervezet a Belügyminisztérium Politikai Nyomozó Főosztály (13 osztály) kisebb módosításokkal megőrizte az államvédelmi időszakban kialakított szerkezeti felépítést.

Az 1960-as évek elején végrehajtott átszervezéssel létrejött a Belügyminisztériumban az az állambiztonsági szervezeti rend, amely - a csoportfönökségi felosztást tekintve - egészen 1990 januárjáig, a Belügyminisztérium III. Főcsoportfönökség megszüntetéséig érvényben maradt.

\section{A titkos információgyüjtésre vonatkozó szabályok a rendszerváltás előtt}

A titkos információgyüjtés a szocialista államrend idején is szigorú szabályok szerint müködött. Ezek a rendeletek nem voltak nyilvánosak, és még a „szocialista törvényesség" akkoriban hangoztatott fogalmának sem feleltek meg.

\footnotetext{
9 Hajma Lajos: A katonai felderítés és hírszerzés története. Egyetemi Jegyzet. ZMNE, Budapest, 2001, 212. 0 .

10 Tóth Eszter: A politikai és gazdasági hírszerzés szervezettörténete 1945-1990. Betekintő, 2011/2., 14. o.
} 
(Különösen nem 1987 után, amikor a jogalkotásról szóló törvény egyértelművé tette, hogy az alapvető jogok korlátozása csak törvényben történhet.)

A következőkben említés szintjén bemutatott belső szabályzatok a korlátozás nélküli egypárti hatalmat voltak hivatottak szolgálni:

- A belügyminiszter 535059/1946. B. M. számú rendelete a magyar államrendőrség államvédelmi osztálya szervezetének, továbbá feladat- és ügykörének megállapítása tárgyában.

- A Minisztertanács 3541/1956. (VIII. 22.) határozata az alkalmazható operatív eszközökről és módszerekről.

- A Minisztertanács 6000/1975. határozata az állambiztonsági feladatokról.

- A Minisztertanács elnökhelyettesének 1/1975. utasítása az állam biztonságának védelmében alkalmazható eszközökröl és módszerekröl.

- A Magyar Népköztársaság belügyminiszterének 26/1979. számú parancsa a Belügyminisztérium III. (Állambiztonsági) Főcsoportfőnökség Ügyrendjének kiadásáról.

\section{A magyar nemzetbiztonsági szolgálatok a rendszerváltás után}

Az Országgyülés 1990. január 25-én fogadta el a különleges titkosszolgálati eszközök és módszerek átmeneti szabályozásáról szóló 1990. évi X. törvényt, valamint a nemzetbiztonsági feladatok ellátásának átmeneti szabályozásáról szóló 26/1990. (II. 14.) MT rendeletet. Utóbbi hatálybalépése után két polgári (Információs Hivatal, Nemzetbiztonsági Hivatal) és két katonai szolgálat (Katonai Biztonsági Hivatal, Katonai Felderítő Hivatal) kezdte meg a müködését.

A Nemzetbiztonsági Szakszolgálat elődszervezetének tekinthető Belügyminisztérium III/V. (operatív-technikai) Csoportfönökséget a föcsoportfönökség szintén operatív-technikai feladatokat ellátó önálló osztályaival együtt Szakszolgálati és Technikai Igazgatóság néven beleillesztették a Belügyminisztérium III/II. (Kémelhárító) Csoportfönökség jogutódjaként létrejött Nemzetbiztonsági Hivatal szervezetrendszerébe.

1995. december 19-én fogadta el az Országgyülés a nemzetbiztonsági szolgálatokról szóló 1995. évi CXXV. törvényt. A jogszabály a Nemzetbiztonsági Hivatalról leválasztotta a titkos információgyüjtéshez technikai hátteret biztosító Nemzetbiztonsági Szakszolgálatot, amelynek kormányzati irányítását - hasonlóan a polgári hírszerzéshez és elhárításhoz - 1996 és 2002, 
valamint 2007 és 2010 között tárca nélküli miniszter, 2002 és 2007 között a Miniszterelnöki Hivatalt vezető miniszter látta el.

Az Nbtv. módosítása után 2010 nyarától az Alkotmányvédelmi Hivatal és a Nemzetbiztonsági Szakszolgálat a belügyminiszter, az Információs Hivatal pedig a külügyminiszter irányítása alá került. A Katonai Felderítő Hivatal és a Katonai Biztonsági Hivatal maradt a honvédelmi miniszter vezetése alatt.

2012. január 1-jén a két katonai szolgálatból megalakult a Katonai Nemzetbiztonsági Szolgálat.

2012. szeptember 1-jétől az Információs Hivatal a Miniszterelnökség irányítása alá került.

\section{A nemzetbiztonsági szolgálatok felügyelete és ellenőrzése}

A szolgálatok felügyeletét az Országgyülés nemzetbiztonsági bizottsága - a Katonai Nemzetbiztonsági Szolgálat esetében a honvédelmi és rendészeti bizottság is - látja el. Jogosult még a szolgálatok ellenőrzésére a költségvetésük tekintetében az Állami Számvevöszék, az állampolgári jogok betartásának ellenőrzésére az Alapvető Jogok Biztosának Hivatala, az adatvédelemi elöírások betartásának vonatkozásában pedig a Nemzeti Adatvédelmi és Információszabadság Hatóság.

A kormány az 1308/2011. (IX. 6.) határozatával létrehozta a miniszterelnök irányításával működő Nemzetbiztonsági Kabinetet és a titkos információgyüjtéssel foglalkozó nemzetbiztonsági, honvédelmi és rendvédelmi szervek vezetőiből álló Nemzetbiztonsági Munkacsoportot. A Nemzetbiztonsági Munkacsoportot a belügy- és a honvédelmi miniszter közösen vezetik. A Nemzetbiztonsági Kabinet szükség szerint, de általában kéthetente, a Nemzetbiztonsági Munkacsoport szükség szerint, de legalább havonta ülésezik.

Az Nbtv.-vel összhangban az Alkotmányvédelmi Hivatal és a Nemzetbiztonsági Szakszolgálat müködése felett a kormányzati irányítási jogkört a belügyminiszter gyakorolja, az Információs Hivatal irányításáért a Miniszterelnöki Hivatalt vezető államtitkár a felelős, a Katonai Nemzetbiztonsági Szolgálatot pedig a honvédelmi miniszter felügyeli. A miniszterek (államtitkár) hatásköre kiterjed az Országgyülés nemzetbiztonsági bizottságával és a parlamenti pártok frakcióvezetőivel való kapcsolattartásra.

A polgári nemzetbiztonsági szolgálatokat irányító minisztert (államtitkárt), jogkörének ellátásában a Belügyminisztérium és a Miniszterelnöki Hi- 
vatal apparátusa segíti. Munkatársai egyrészt a Belügyminisztérium és a Miniszterelnöki Hivatal állományába tartozó kormánytisztviselők, másrészt a szolgálatoktól berendelt hivatásos állományú tisztek.

Az Országgyülés nemzetbiztonsági bizottságának feladatai a következök:

- Kivizsgálhatja a nemzetbiztonsági szolgálatok jogellenes tevékenységére utaló panaszokat.

- Ha valamely nemzetbiztonsági szolgálat jogszabályellenes vagy nem rendeltetésszerủ tevékenységét feltételezi, vizsgálat lefolytatására felkérheti a minisztert.

- Ha valamely nemzetbiztonsági szolgálat jogszabályellenes müködését észleli, ténymegállapító vizsgálatot folytathat le.

- Ha bármely módon valamely nemzetbiztonsági szolgálat jogszabályellenes vagy nem rendeltetésszerü müködését észleli, felhívhatja a minisztert a szükséges intézkedés megtételére, és kezdeményezheti a felelősség megvizsgálását.

- Véleményezi a nemzetbiztonsági szolgálatok költségvetésének részletes tervezetét, a titkos információgyűjtésre jogosult egyéb szervezetek költségvetésének e tevékenységgel kapcsolatos tételeit, illetve az éves költségvetési törvény végrehajtásáról szóló részletes beszámoló tervezetét, a törvényjavaslatok tárgyalásakor az elfogadásra vonatkozóan javaslatot tesz az Országgyülésnek.

- Kinevezésük elött meghallgatja a föigazgatói tisztségre jelölt személyeket, alkalmasságukról állást foglal. ${ }^{11}$

\section{A hazai nemzetbiztonsági szolgálatok}

\section{Alkotmányvédelmi Hivatal}

Az Alkotmányvédelmi Hivatal müködésének célja az állampolgárok és Magyarország alkotmányos rendjének védelme, biztonságuk garantálása. A hivatal a belügyminiszter irányításával hajtja végre a nemzetbiztonsági törvényben számára meghatározott feladatokat. Együttmüködik a Belügyminisztérium rendvédelmi szerveivel, a nemzetbiztonsági szolgálatokkal és az államigazgatás más területeivel. Széles körủ együttmüködést folytat döntően a NATO-tagországokkal és az Európai Unió partnerszolgálataival.

11 1995. évi CXXV. törvény a nemzetbiztonsági szolgálatokról 14. § (4) bek. 
A rendelkezésére álló - törvényi felhatalmazással alkalmazott - eszközökkel és módszerekkel felismeri és azonosítja a nemzet biztonságát fenyegető rejtett és nyílt veszélyeket, az azokat megjelenítő szervezeteket és személyeket, s hatékonyan lép fel mindezekkel szemben. Kiemelt feladata, hogy Magyarország kormánya számára megszerezze a döntéshozatalhoz szükséges - más módon be nem szerezhetó - információkat.

Feladatai: kémelhárítás, alkotmányvédelem, gazdaságbiztonság, nemzetbiztonsági védelem, nemzetbiztonsági ellenőrzések, közremüködés az idegenrendészeti eljárásokban, nemzetközileg ellenőrzött termékek és technológiák jogellenes forgalmának felderítése, megelőzése, megakadályozása és legális forgalmának ellenőrzésében közremüködés (proliferáció), iparbiztonsági ellenőrzések. ${ }^{12}$

\section{Információs Hivatal}

A 2012. évi XCVI. törvény módosította az Információs Hivatal irányítását. A CXXV. törvény 4. § (3) pontja a következök szerint változott: ,,Ha a Kormány $a z$ Információs Hivatalt a miniszterelnök útján irányítja, az irányitással összefüggö egyes hatásköröket a miniszterelnök a Miniszterelnökség szervezeti és müködési szabályzatában a Miniszterelnökséget vezetö államtitkárra átruházhatja." Az államtitkárságon belül egy helyettes államtitkár vezetésével létrejött egy szakapparátus, amely az államtitkár és a miniszterelnök munkáját segíti a nyílt és titkos információgyüjtés eszközeivel és módszereivel megszerzett adatok feldolgozásával, értékelésével, elemzésével és a kormányzati hírigények megfogalmazásával.

Az Információs Hivatal polgári hírszerző szolgálat, amely elsődlegesen az országhatáron kívül tevékenykedik. Általános rendeltetése, hogy a külföldre vonatkozó vagy külföldi eredetủ bizalmas információk megszerzésével segítse elő a magyar nemzeti érdekek érvényesülését, müködjék közre Magyarország függetlenségének fenntartásában és törvényes rendjének védelmében.

A hírszerzési információk a kormányzati döntések megalapozását szolgálják. A kormány meghatározza azokat a témákat, amelyekről a hírszerzés útján tájékozódni kíván. E hírigények alapulvételével az Információs Hivatal különleges eszközrendszere révén - olyan adatokat, értesüléseket, dokumentumokat szerez, amelyek a hivatalos csatornákon egyáltalán nem vagy csak korlátozottan ismerhetők meg.

12 http://ah.gov.hu/html/nbh_tortenete.html 
Feladata teljesítése érdekében a hivatal mủveleti tevékenységet folytat. Humán és müszaki-tudományos eszközökkel létrehozott forrásokból titkos és bizalmas adatokat ismer meg, emellett nyilvános forrásokat is felhasznál, s kiaknázza a nemzetközi együttmüködésben rejlő lehetőségeket is. A megszerzett információkat elemzi, a már rendelkezésre állókkal összeveti és értékeli, majd hírszerző jelentéseket készít, amelyeket a döntéshozóknak továbbít.

A hivatal a Miniszterelnökséget vezető államtitkár szerint az Országgyülés nemzetbiztonsági bizottságának jegyzőkönyve alapján profilváltást kell hogy végrehajtson, és a továbbiakban felderítő tevékenységének új iránya az ország pénzügyi-gazdasági biztonságának garantálása, az ehhez szükséges információk beszerzése kell hogy legyen. ${ }^{13}$

\section{Katonai Nemzetbiztonsági Szolgálat}

A szolgálat a kormány irányítása alatt álló, az ország egész területére kiterjedő illetékességü, önálló gazdálkodást folytató költségvetési szerv. A Katonai Nemzetbiztonsági Szolgálat 2012. január 1-jén jött létre a honvédelmi miniszter 128/2011. (XII. 2.) utasításával, amely a Magyar Köztársaság Katonai Felderítő Hivatal megnevezést Katonai Nemzetbiztonsági Szolgálat megnevezésre változtatta, míg a Magyar Köztársaság Katonai Biztonsági Hivatal megszünt mint önálló költségvetési szerv, szervezeti egységei pedig beolvadtak a Katonai Nemzetbiztonsági Szolgálat szervezetébe. ${ }^{14}$

Rendeltetése: a Katonai Nemzetbiztonsági Szolgálat a nemzetbiztonsági szolgálatokról szóló 1995. évi CXXV. törvényben meghatározott - hírszerző, elhárító, védelmi és ellenőrzési - feladatok elvégzésével, a nyílt és a titkos információgyüjtés eszközrendszerével müködési területén elősegíti Magyarország nemzetbiztonsági érdekeinek érvényesítését, ezáltal közremúködik az ország függetlenségének és törvényes rendjének védelmében.

A szolgálat müködésének jogi alapjait, feladatait, a hozzá kötődő szervezeti és eszközrendszert, az irányítási és az ellenőrzési jogosultságot, a jogi és politikai garanciákat a nemzetbiztonsági szolgálatokról szóló, a 2011. évi CLXXI. törvénnyel módosított 1995 . évi CXXV. törvény biztosítja.

A Katonai Nemzetbiztonsági Szolgálatot a kormány a honvédelmi miniszteren keresztül irányítja. A miniszter irányítási jogköre átfogja a Katonai Nemzetbiztonsági Szolgálattal kapcsolatos államigazgatási és költségvetési irányítási jogok teljes körét. A szolgálat müködésének általános kereteit, szer-

13 Napi Gazdaság, 2012. október 24

14 Honvédelmi Közlöny, CXXXVIII. évfolyam 18. szám, 1699-1700. o. 
vezeti felépítését, konkrét feladatkörét a honvédelmi miniszter rendeletekben és utasításokban határozza meg. A Katonai Nemzetbiztonsági Szolgálat élén a föigazgató áll, akit a honvédelmi miniszter előterjesztésére a miniszterelnök nevez ki és ment fel. A föigazgató a törvények, jogszabályok és az állami irányítás egyéb jogi eszközei által meghatározott keretek között önálló felelősséggel vezeti a szolgálatot.

A nemzetbiztonsági szolgálatokról szóló törvényben meghatározottak szerint a Katonai Nemzetbiztonsági Szolgálat felett két országgyülési bizottság gyakorol ellenőrzési jogkört: az Országgyülés nemzetbiztonsági és a honvédelmi és rendészeti bizottsága.

A nemzetbiztonsági bizottság a Katonai Nemzetbiztonsági Szolgálat alkotmányos, törvényes müködését ellenőrzi a törvényhozás politikai eszközeinek alkalmazásával, a honvédelmi és rendészeti bizottság pedig az ország védelmi képessége szempontjából ellenőrzi a speciális feladatokat ellátó szolgálat általános tevékenységét. A nemzetbiztonsági bizottság megkapja a szolgálat által a kormány számára készített - nemzetbiztonsági kérdéseket érintő - értékeléseket, jelentéseket. A bizottságokat a honvédelmi miniszter rendszeresen tájékoztatja a szolgálat tevékenységéről, az ország és a honvédelmi szféra biztonsági helyzetéről, illetve a Katonai Nemzetbiztonsági Szolgálat törvényben előírt feladatainak teljesítéséről. ${ }^{15}$ A Katonai Nemzetbiztonsági Szolgálat főigazgatója évente kétszer köteles beszámolni mindkét parlamenti bizottság elött.

Feladatai a következök:

- Felderíti és elhárítja a Magyarország elleni támadó szándékra, külföldi titkosszolgálati tevékenységre, a törvényes rend jogellenes eszközökkel történő megváltoztatására vagy megzavarására, terrorcselekmény elkövetésére irányuló törekvéseket.

- Megszerzi a kormányzati döntéseket megalapozó katonapolitikai, hadiipari és katonai információkat, valamint a Honvédelmi Minisztérium, illetve a Honvéd Vezérkar hadászati-hadműveleti, információvédelmi tervező munkájához szükséges adatokat.

- Információkat gyűjt a müködési területét érintő szervezett bűnözésröl, az Nbtv. által hatáskörébe utalt, valamint a Honvédelmi Minisztérium és a Magyar Honvédség törvényes feladatainak végrehajtását veszélyeztető büncselekményekről, a honvédelmi érdeket sértő kibertevékenységről, továbbá a műveleti területén lévő alakulatok és azok állománya ellen irányuló törekvésekről és tevékenységekröl.

15 1995. évi CXXV. törvény a nemzetbiztonsági szolgálatokról 17. §. 
- Ellátja a Honvédelmi Minisztérium és a Magyar Honvédség szervezeteinél folytatott hadiipari kutatással, fejlesztéssel, gyártással és kereskedelemmel összefüggö, valamint a nemzetközileg ellenörzött termékekhez és technológiákhoz, továbbá a haditechnikai eszközök és szolgáltatások jogellenes forgalmának felderítéséhez, megelőzéséhez, megakadályozásához és legális forgalmának ellenőrzéséhez kapcsolódó nemzetbiztonsági feladatokat.

- Elvégzi az illetékességébe tartozó fontos és bizalmas munkakört betöltő személyekhez, gazdálkodó szervezetekhez, a speciális beszerzésekhez, katonai rendezvényekhez és gyakorlatokhoz kötődő minősítési, ellenőrzési és védelmi feladatokat.

- Végrehajtja a katonadiplomáciai tevékenységből a Katonai Nemzetbiztonsági Szolgálatra háruló feladatokat. A véderő, katonai és légügyi attasék útján biztosítja a Honvédelmi Minisztérium és a Magyar Honvédség külföldön tartózkodó vezetői delegációinak program-előkészítését, -lebonyolítását és a feladataik végrehajtásához szükséges támogatást.

\section{A Nemzetbiztonsági Szakszolgálat}

Hazánk legnagyobb költségvetésü, legnagyobb létszámú, tevékenységében a legösszetettebb, legtagoltabb nemzetbiztonsági szolgálata.

A Nemzetbiztonsági Szolgálatok címszó alatt a kormány hivatalos honlapján a következő megfogalmazás olvasható: „, A Nemzetbiztonsági Szakszolgálat a magyar állam elsö rendjének védelme érdekében, szigorú jogszabályi keretek között nyilt és titkos információgyüjtést végez az erre felhatalmazott szervek kérésére." 16

A Nemzetbiztonsági Szakszolgálat a kormány irányítása alatt álló, az ország egész területére kiterjedő illetékességü, önálló gazdálkodást folytató költségvetési szerv.

Nem a „hagyományos” értelemben vett nemzetbiztonsági szolgálat, hiszen önálló hatáskörben titkos adatgyüjtést nem folytat; tevékenysége túlmutat a nemzetbiztonsági érdekkörön.

Az Nemzetbiztonsági Szakszolgálat feladatait a Nbtv. 8. § (1) pontja a következők szerint határozza meg:

- jogosult a jogszabályok keretei között a titkos információgyüjtés, illetve a titkos adatszerzés eszközeivel és módszereivel - írásbeli megkeresésre szolgáltatást végezni a titkos információgyüjtésre, illetve a titkos adatszer-

16 http://www.kormany.hu/hu/mo/rendvedelem/nemzetbiztonsagi-szolgalatok 
zésre feljogosított szervek titkos információgyűjion, valamint titkos adatszerző tevékenységéhez;

- a törvény által a titkos információgyüjtésre, illetve a titkos adatszerzésre feljogosított szervek igényei alapján biztosítja az e tevékenységhez szükséges különleges technikai eszközöket és anyagokat;

- speciális távközlési összeköttetést biztosít a kormány által meghatározott felhasználók részére;

- ellátja a biztonsági okmányok védelmével összefüggő hatósági felügyeletet;

- szakértői, illetve - külön jogszabály rendelkezései szerint - igazságügyi szakértői tevékenységet végez;

- végzi a hatáskörébe tartozó személyek, valamint a 68. § (4) bekezdés f) pontjában meghatározott személyek nemzetbiztonsági ellenőrzését, illetve ellátja az objektumai műveleti védelmét;

- elvégzi a minősített adatot, az ország alapvetö biztonsági, nemzetbiztonsági érdekeit érintő vagy a különleges biztonsági intézkedést igénylő beszerzések sajátos szabályairól szóló kormányrendelet szerinti kiegészítő ellenőrzést ${ }^{17}$.

\section{A titkos információgyüjtésre jogosult egyéb hazai szervezetek}

A 2010-es év számos változást hozott a rendvédelmi szervek életében. Új szervezetek alakultak, például a Terrorelhárítási Központ. Más szervezetek pedig kibővült és módosított feladatrendszerrel müködnek tovább, ilyen például a Nemzeti Védelmi Szolgálat és a Nemzeti Adó- és Vámhivatal.

\section{Nemzeti Adó- és Vámhivatal}

A hivatalt 2011. január 1-jén hozták létre az Adó- és Pénzügyi Ellenőrzési Hivatal (APEH) és a Vám- és Pénzügyőrség Országos Parancsnoksága (VPOP) összevonásával. A hivatalon belül a jogszabály a Bünügyi Főigazgatóságot hatalmazta fel titkos információgyüjtő tevékenységre.

A Bünügyi Főigazgatóság különös hatásköri szabályai a következők: 33. § A Bünügyi Főigazgatóság hatáskörébe tartozik, országos illetékességgel a Be. által az adóhatóság hatáskörébe utalt büncselekmények tekintetében:

17 1995. évi CXXV. törvény a nemzetbiztonsági szolgálatokról 8. § (1) pont. 
a) az 500 millió forintot meghaladó értékre üzletszerüen (Btk. 137. § 9. pont) vagy bünszövetségben (Btk. 137. § 7. pont) elkövetett büncselekmények nyomozása;

b) a bünszervezet (Btk. 137. § 8. pont) tagjaként elkövetett büncselekmények nyomozása;

c) az a) és a b) pontokba nem tartozó olyan büncselekmények nyomozása, amelyeket az elkövető személye, vagy az elkövetés körülményei, illetve a büncselekmény társadalomra veszélyességének kiemelkedő foka miatt a Bünügyi Főigazgatóság föigazgatója vagy az adóhatóság elnöke a Bünügyi Főigazgatóság hatáskörébe von, illetve utal.

34. $\S$ A bünügyi föigazgató egyedi ügyekben a 33. § a) és b) pontjában meghatározott nyomozó hatósági jogkörét regionális bünügyi igazgatóságra ruházhatja át, amennyiben ezt a nyomozási cselekmények hatékonyabb elvégzése indokolja.

35. $\S$ A Bünügyi Főigazgatóság ellátja a Be. által a Nemzeti Adó- és Vámhivatal hatáskörébe utalt büncselekmények tekintetében az adóhatóságra vonatkozó törvényben meghatározott fedett nyomozati tevékenységgel kapcsolatos feladatokat.

36. § A regionális bünügyi igazgatóságok a 33. §-ban meghatározott kivétellel végzik a Be. 36. § (2) bekezdésében meghatározott büncselekmények megelőzését, felderítését, valamint nyomozását az erre vonatkozó jogszabályok rendelkezései szerint.

\section{Nemzeti Védelmi Szolgálat}

2011. január 1-jén jött létre a Nemzeti Védelmi Szolgálat, a korábbi Rendvédelmi Szervek Védelmi Szolgálata bázisán, nagyobb létszámmal és kibővített hatáskörrel. A Nemzeti Védelmi Szolgálat a belügyminiszter irányítása alatt müködik. Az általuk védendő állomány létszáma nagyjából százezer, a három nagy szakmai területen: a rendvédelmi szervek, a polgári titkosszolgálatok és közigazgatási szervek területén.

A Nemzeti Védelmi Szolgálat célja a szervezetek állományának megvédése a nem odavaló, sok kárt okozó tisztességtelen munkatársak ellen. A rendvédelmi szervek közös harcaként fogalmazza meg a korrupció elleni fellépést, amelynek eszközeit az Országgyülés törvény formájában az Nemzeti Védelmi Szolgálat rendelkezésére bocsátotta. 
A kifogástalan életvitel ellenőrzése olyan eszköz, amely már a jelentkezés során is lehetőséget kínál arra, hogy valóban megvédelmezhessék a védett állományt azoktól, akik nem valók közéjük.

A megbízhatósági vizsgálat - amelynek jogi garanciája az ügyészi jóváhagyás - nem a tisztességesen szolgálók zaklatását jelenti, hiszen nekik nem kell ettől tartaniuk.

A Nemzeti Védelmi Szolgálat céljai a következők:

- az államhatalom végrehajtó szervei iránti bizalom helyreállítása;

- a hatáskörükbe tartozó szerveknél dolgozók védelme;

- az állami szolgálat tekintélyének visszaállítása.

\section{Az Nemzeti Védelmi Szolgálat törvényességi, ügyészi felügyelete}

Az ügyészség a büntetőeljárásról szóló törvényben meghatározott feltételek szerint nyomozást végeztet és nyomoz; ha a nyomozó hatóság önállóan végez nyomozást vagy egyes nyomozási cselekményeket, az ügyészség felügyel arra, hogy azt a törvény rendelkezéseit megtartva végezzék, törvényben meghatározott egyéb jogokat gyakorol a nyomozással összefüggésben, képviseli a vádat a bírósági eljárásban, továbbá felügyeletet gyakorol a rendőrségről szóló törvényben meghatározott megbízhatósági vizsgálat, valamint a büntetés-végrehajtás törvényessége felett.

Az Nemzeti Védelmi Szolgálat által védett szervezetek a következök:

- Alkotmányvédelmi Hivatal;

- Bevándorlási és Állampolgársági Hivatal;

- Belügyminisztérium Nemzetközi Oktatási Központ;

- Belügyminisztérium Oktatási Képzési és Tudományszervezési Főigazgatóság;

- Büntetés-végrehajtás Országos Parancsnoksága;

- Nemzeti Adó- és Vámhivatal;

- Nemzetbiztonsági Felügyelet;

- Nemzeti Közszolgálati Egyetem Rendészettudományi Kar;

- Nemzetbiztonsági Szakszolgálat;

- Országos Katasztrófavédelmi Főigazgatóság;

- rendörség;

- Terrorelhárítási Központ;

A Nemzeti Védelmi Szolgálat hatásköre nem terjed ki az Információs Hivatalra és a Katonai Nemzetbiztonsági Szolgálatra. ${ }^{18}$

$18 \mathrm{http}: / / \mathrm{nvsz} \cdot \mathrm{hu} / \mathrm{hu}$ 
A rendőrség titkos információgyüjtéssel kapcsolatos feladatait és lehetőségeit a rendőrségi törvény határozza meg. Alapvetően ezt a feladatot a bűnügyi (felderítő) állomány és kiemelten a Készenléti Rendőrség állományába tartozó Nemzeti Nyomozó Iroda munkatársai végzik.

\section{Terrorelhárítási Központ}

A Terrorelhárítási Központ a 232/2010-es kormányrendelettel 2010. szeptember 1-jén megalapított, a belügyminiszter irányítása alá tartozó magyarországi országos hatáskörü állami szervezet.

Feladatai közé tartozik Magyarország terrorfenyegetettségének elemzése-értékelése, a kormányfö védelme, a Magyarország területén történt terrorcselekmények, emberrablások felderítése.

A szervezet részben a Köztársasági Örezredből, a megyei bevetési osztályokról, az Országos Rendőr-főkapitányság Nemzeti Nyomozó Iroda teljes terrorizmus és extrémizmus elleni osztályából, a Készenléti Rendőrségen belüli Terrorelhárító Szolgálattól és az Alkotmányvédelmi Hivataltól átcsoportosított állományból alakult meg.

A terrorizmust elhárító szerv személyi állománya jelenleg az általános rendőrségi feladatok ellátására létrehozott szervtől a hivatásos szolgálati viszonyra vonatkozó jogszabály szerint berendelt rendőrökből és vezényelt hivatásos állományúakból, valamint közalkalmazottakból áll.

\section{Ügyészség}

Magyarország Alaptörvénye szerint a legfőbb ügyész és az ügyészség az igazságszolgáltatás közremüködőjeként az állam büntetőigényét érvényesíti. Az ügyészség üldözi a bűncselekményeket, fellép más jogsértő cselekményekkel és mulasztásokkal szemben, valamint elösegíti a jogellenes cselekmények megelőzését.

A legfőbb ügyész és az ügyészség törvényben meghatározottak szerint jogokat gyakorol a nyomozással összefüggésben, képviseli a közvádat a bírósági eljárásban, felügyeletet gyakorol a büntetés-végrehajtás törvényessége felett, törvény által meghatározott további feladat- és hatásköröket gyakorol. 
Az Országgyülés az ügyészség tevékenységét kétféle módon: az éves legföbb ügyészi beszámoló, illetve a legföbb ügyésznek a rendelkező rész szerinti korlátozott válaszadási kötelezettségén keresztül ellenőrzi.

Jelenleg a Legfőbb Ügyészség irányítása alatt fellebbviteli föügyészségek, föügyészségek, és járási ügyészségek müködnek. ${ }^{19}$

A titkos információgyüjtés szabályozásáról az ügyészségről szóló 2011. évi CLXIII. törvény 18. §-a rendelkezik.

(1) Az ügyészségi nyomozás elrendeléséig - a rendőrségi törvényben meghatározott okokból és szabályok szerint - titokban információ gyüjthető. Ahol a rendőrségi törvény a titkos információgyüjtés körében a rendőri szerv vagy annak vezetője számára állapít meg jogokat és kötelezettségeket, ott az ügyészségi nyomozást végző ügyészi szervet vagy annak vezetőjét kell érteni.

(2) Ha a rendőrségi törvény a bírói engedélyhez nem kötött titkos információgyüjtés keretében végzett cselekményhez az ügyész engedélyét (hozzájárulását, jóváhagyását) írja elő, az engedélyezés jogkörét a felettes ügyész gyakorolja.

(3) Az ügyész (felettes ügyész) a titkos információgyüjtés elvégzése érdekében - a feljelentés elutasításának, vagy a nyomozás megszüntetésének kilátásba helyezése, valamint az adatkérés kivételével - a nyomozó hatóságot utasítja vagy titkos információgyüjtés végzésére jogosult más szolgálatot (hivatalt) megkeresi.

(4) Ha a titkos információgyüjtés szükségessége a nemzetbiztonsági szolgálatok (hivatalok) hivatásos állományú tagját érintően merül fel, az ügyész e tényről tájékoztatja azon szolgálat föigazgatóját, amelynek állományába az érintett személy tartozik. A titkos információgyüjtés elvégzésére ilyen esetben az ügyész az érintett nemzetbiztonsági szolgálatot (hivatalt) is felkérheti.

(5) Az ügyészségi nyomozás során a bírói engedélyhez kötött titkos adatszerzésre a büntetőeljárási törvény rendelkezései az irányadók.

\section{A nemzetbiztonsági tevékenységet segítő és támogató szervezetek}

Nemzeti Biztonsági Felügyelet

A Nemzeti Biztonsági Felügyeletet mint a NATO minősített adatok védelméért és szakmai felügyeletéért felelős szervezetet, a Nemzeti Biztonsági Fel-

19 2011. évi CLXIII. törvény az ügyészségről 8. § 
ügyeletről szóló 1998. évi LXXXV. törvény hozta létre. Az azóta eltelt időszakban a felügyelet feladatköre folyamatosan bővült, elsőként az uniós minősített adatok, majd később a nemzeti minősített adatok védelmével és szakmai felügyeletével. Ebben a folyamatban mérföldkövet jelentett a minösített adat védelméről szóló 2009. évi CLV. törvény elfogadása, amely alapjaiban szabályozta újra a honi titokvédelem struktúráját. Ily módon, a jogszabály 2010. április 1-jei hatálybalépése óta a felügyelet egyfajta „titokvédelmi főhatóságként" müködik 2015 óta a Belügyminisztérium szervezeti keretében.

A Nemzeti Biztonsági Felügyelet

- a minősített adatot kezelő szervnél engedélyezi a minősített adatok kezelését, jogosult a kiadott engedély módosítására vagy visszavonására;

- engedélyezi a minősített adatok kezelésére szolgáló elektronikus rendszerek használatba vételét, jogosult a kiadott engedély módosítására vagy viszszavonására;

- nyilvántartja az előző két pontban meghatározott engedéllyel bíró minősített adatot kezelő szerveket nevük és székhelyük feltüntetésével;

- a minősített adatot kezelő elektronikus rendszerekről megfelelőségi igazolások alapján tanúsítványt ad ki;

- ellátja a rejtjeltevékenység hatósági engedélyezését és felügyeletét;

- egyetértési jogot gyakorol a minősített adatot kezelő szervek biztonsági vezetőinek kinevezésével kapcsolatban;

- ellenőrzi a minősítők minősítési gyakorlatát, ennek eredményeként egyedi vagy általános ajánlást bocsáthat ki az egységes minősítési gyakorlat kialakítása érdekében, illetve kezdeményezheti a minősítés felülvizsgálatát;

- ellátja a minősített adatot kezelő szervnél a minősített adat kezelésének hatósági felügyeletét, ellenőrzi a minősített adat védelmére vonatkozó jogszabályok, valamint a személyi, fizikai, adminisztratív és elektronikus biztonsági szabályok betartását;

- arra jogosult gazdálkodó szervezetek részére telephely-biztonsági tanúsítványt ad ki, jogosult a telephely-biztonsági tanúsítvány módosítására vagy a már kiadott tanúsítvány visszavonására;

- kivizsgálja a minősített adatok védelmét érintő bejelentéseket;

- a minősített adatot kezelő szervnél kivizsgálja a minősített adatok elvesztésével, illetéktelen személy tudomására jutásával, valamint a biztonság megsértésével kapcsolatos eseményeket;

- gondoskodik a jogutód nélkül megszünt szervek által keletkeztetett minősített adatok felülvizsgálatának elvégzéséről; 
- ellátja az Európai Unió Tanácsa, az Európai Bizottság, az Euratom, az Europol, az Eurojust (a továbbiakban együtt: EU), a NATO, a Nyugat-európai Unió, valamint vonatkozó szabályzataiban és a minősített adatok védelme tárgyában kötött nemzetközi szerződésekben a nemzeti biztonsági hatóságok számára elöírt feladatokat;

- kapcsolatot tart a NATO, a Nyugat-európai Unió, az EU és a tagállamok illetékes szervezeteivel, és tevékenységéröl - a szükséges mértékben - tájékoztatja őket;

- ellátja a nemzeti érdekérvényesítést a minősített adatok védelmét érintő nemzetközi bizottságokban és munkacsoportokban;

- részt vesz a minősített adatok cseréjével járó két- vagy többoldalú biztonsági megállapodások, továbbá valamennyi olyan nemzetközi szerződés elökészítésében, amely minősített adatokat is érint;

- gondoskodik a biztonsági vezetők részére tartandó képzésről és továbbképzésröl;

- együttműködik az adatvédelmi biztossal a közérdekủ adatok megismeréséhez füződő alkotmányos jog tiszteletben tartása és az információszabadság érvényesülése érdekében;

- végzi az elektronikusadat-kezelő rendszerek vagy azok elemeinek elektromágneses kompromittáló kisugárzásának méréseit, és ezek alapján meghatározza azok zónabesorolását;

- végzi a helyiségek elektromágneses kompromittáló kisugárzásának védelmével összefüggő méréseket, ezek alapján meghatározza azok zónabesorolását. ${ }^{20}$

\section{Szervezett Bünözés Elleni Koordinációs Központ}

A Szervezett Bűnözés Elleni Koordinációs Központot a kormány az egyes miniszterek, valamint a Miniszterelnökséget vezető államtitkár feladat- és hatásköréröl szóló 212/2010. (VI. 1.) kormányrendelet 37. § f) pontja alapján a belügyminiszter irányítja.

A Szervezett Bűnözés Elleni Koordinációs Központ tehát a belügyminiszter vezetése alatt müködő központi hivatal, amely a szervezett bünözés megelőzésének, megszakításának elősegítése érdekében - jogszabályban meghatározott együttmüködők által megküldött - adatokat gyüjt, felelős ezek felhasználásáért, ellenőrzéséért és koordinációjáért. A Szervezett Bünözés El-

20 http://www.nbf.hu/ 
leni Koordinációs Központ az ország egész területére kiterjedő illetékességgel felruházott, központi költségvetési szerv.

A központ megalapítására a szervezett bünözés elleni tevékenység támogatása, koordinációja érdekében a Szervezett Bünözés Elleni Koordinációs Központról szóló 2000. évi CXXVI. törvény alapján 2001. január 1-jei hatállyal került sor.

Feladata: a szervezett bünözés megelőzésének, megszakításának, felderítésének elősegítése céljából a szervezett bünözés elleni fellépés céljából feldolgozott adatok gyüjtésének, felhasználásának és ellenőrzésének koordinációja.

\section{Alaptevékenysége:}

- a szervezett bünözés, valamint az azzal összefüggő egyes jelenségek elleni fellépés szabályairól és az ehhez kapcsolódó törvénymódosításokról szóló 1999. évi LXXV. törvény 4/A §-ában meghatározott együttmüködő szervek részéröl a hatáskörébe utalt bủncselekményekröl küldött adatok gyủjtése, elemzése és értékelése, igénylő együttmüködő szervhez továbbítása, illetve hatáskörrel és illetékességgel bíró együttmüködő szervhez történő megküldése, továbbá az adathoz kapcsolható, azt kiegészitő vagy azzal összefüggő adatokról az érintett együttműködő szervek értesítése;

- a hatáskörébe utalt büncselekmények gyanúja miatt elrendelt felderítésekről küldött adatok alapján annak figyelemmel kísérése, hogy az együttmüködő szerveknél nem folyik-e párhuzamos felderítés, ennek észlelése esetén az érintett szervek értesítése;

- az elemző-értékelő tevékenység alapján felderítési, nyomozási cselekményre, intézkedésre történő javaslattétel;

- az illetékességébe tartozó büncselekmények megalapozott gyanúja miatt indult büntetőeljárásokról küldött adatok figyelemmel kísérése, a felderítésekről küldött adatokkal történő összevetése, elemzése, értékelése;

- az együttműködő szervek szervezett bünözésben és terrorszervezetben szerepet játszó bünöző csoportok elleni fellépésének segítése a csoportok alakulásának és megszünésének, egymáshoz való viszonyának figyelemmel kísérésével, jogellenesen szerzett javaik legalizálását szolgáló vállalkozásaik elemzésével;

- a szervezett bünözés és terrorizmus elleni kormányzati döntésekhez történő segítségnyújtás a rendelkezésre álló adatok elemzésével készített helyzetértékelések és statisztikai adatok szolgáltatásával; 
- a hatáskörébe utalt büncselekmények terén jelentkezö tendenciák, új jelenségek, biztonsági kockázatok figyelemmel kísérése, ezekről elemzések, tanulmányok készítése;

- az adatkezelési rendszeréből az együttmüködő szerv, illetve a Legfőbb Ügyészség kérésére adatszolgáltatás;

- közremüködés az együttmüködő szervek vezetői által kijelölt központi szervek és a Szervezett Bünözés Elleni Koordinációs Központ közötti adatátviteli rendszer tervezésében, müködtetésében, fejlesztésében. ${ }^{21}$

Megállapítható, hogy a rendszerváltozással teljesen átalakult a katonai és polgári hírszerzés és elhárítás rendszere. Létrejöttek a szolgálatok müködését szabályozó nyílt és átlátható jogszabályi keretek, és kialakultak a szolgálatok demokratikus ellenőrzésére hivatott szervezetek.

A nemzetközi és hazai fenyegetettségekre reagálás nyomán átszervezésekre, új szervezetek létrehozására és modern informatikai, technikai rendszerek kialakítására, alkalmazására került sor.

Az ország NATO- és uniós csatlakozása egyrészt új kötelezettségeket rótt ránk, másrészt új együttműködési lehetőségeket is teremtett. Természetesen ezekkel együtt megjelentek az új fenyegetettségek, és az új veszélyforrások is, amelyekre a megfelelő választ csakis a szövetségi rendszerből adódó lehetőségek kihasználásával tudjuk megadni.

\section{A nemzetközi biztonsági próbatételek}

A 2001. szeptember 11-i amerikai terrortámadás teljesen új alapokra helyezte a nemzetközi terrorizmus és szervezett bünözés elleni küzdelmet. Érvényes ez a titkos információgyüjtéssel kapcsolatos nemzetek közötti és az országon belül müködő rendvédelmi (nemzetbiztonsági) szervek együttmüködésére egyaránt.

Nem kerülhették el a változások az olyan nagy nemzetközi szervezeteket sem, mint a NATO vagy az Európai Unió. A változások már a kétpólusú világ szembenállásának megszünésével elkezdődtek. A NATO a nemzetközi békefenntartásban találta meg a szövetség új feladatát. Az EU a folyamatos bővülés folytán egyre újabb és újabb biztonsági kockázatokkal találja szemben magát.

21 A Szervezett Bünözés Elleni Koordinációs Központ Alapító Okirata (a módosításokkal egységes szerkezetben). A-176/2/2010,1-2. o. 
Az információs technológia (IT) robbanásszerü fejlődése pedig egy új, eddig szinte ismeretlen világ biztonsági veszélyeit vetíti előre. Ez pedig a kiberbiztonság, a kiberterrorizmus és -bűnözés.

Mindeme változások új helyzetet teremtettek mind a nemzetközi szervezetek, mind a nemzetállamok számára. Mindannyiunk elemi érdeke, hogy választ tudjunk adni ezen kérdésekre, és garantálni tudjuk az állampolgárok biztonságát. Szövetségi és nemzeti szinten stratégiák és tervek készültek, készülnek, új szervezetek jönnek létre, új eszközök rendszeresítésére kerül sor az említett veszélyek csökkentésére.

\section{NATO}

Összhangban az Egyesült Nemzetek Alapokmányának 51. cikkelyével, a Washingtonban, 1949. április 4-én aláírt Észak-atlanti Szerződés kollektív védelmi szövetséget hozott létre. Hazánk 1999. március 12-én vált a NATO teljes jogú tagjává. A szövetség fő politikai döntéshozó szerve az Észak-atlanti Tanács. A tanács elnöke a NATO-fötitkár. A döntések politikai megvalósítása a NATO brüsszeli civil központján keresztül történik, a katonai célkitüzéseket pedig a tanács felügyeletével a NATO Katonai Bizottsága valósítja meg. ${ }^{22}$

A NATO eredményes müködéséhez elengedhetetlen egy jól szervezett hírszerzési és elhárítási rendszer. A szövetség az elmúlt tíz évben folyamatosan korszerüsítette és bővítette hírszerzési szervezeteit, és intenzív koordinációs rendszert hozott létre a tagállamok hírszerző és elhárító szerveivel. Az Északatlanti Tanács szintjén egy hírszerző irányító testület, egy polgári hírszerzési bizottság és egy katonai hírszerzési bizottság müködik. A polgári hírszerzési bizottságban a tagállamok polgári nemzetbiztonsági szervei képviseltetik magukat.

A főtitkárság nemzetközi törzsében és katonai törzsében is helyet kapott egy-egy hírszerző osztály, valamint a NATO-hoz delegált nemzeti összekötő törzsekben is dolgoznak hírszerző tisztek. A hírszerző osztályok szoros együttmüködést alakítottak ki a Nemzetközi Bűnügyi Rendőrség Szervezetével (Interpol) és ez Európai Rendőri Hivatallal (Europol).

A két stratégiai parancsnokság állományában (szövetséges müveleti parancsnokság, szövetséges átalakítási parancsnokság), az összhaderőnemi parancsnokságokon, a haderőnemi parancsnokságokon (haditengerészeti, légi és szárazföldi) és a különböző hadszíntér-parancsnokságokon szintén hírszer-

22 NATO Kézikönyv. HM Stratégiai Védelmi Hivatal-NATO Információs és Sajtóiroda, 2001, 219. o. 
ző osztályok müködnek. A tagállamok katonai és polgári szolgálatainak tisztjei részére hírszerző és elhárító tanfolyamokat szerveznek a NATO németországi (Oberammergau) iskoláján, és képzéseket a romániai (Nagyvárad) NATO Felderítő Kiválósági Központban.

\section{Az Európai Unió hírszerzö-információs rendszere}

Az Európai Uniónak megalakulása óta szüksége van az idejében rendelkezésre álló, megbízható, az unió biztonságára befolyással bíró hírszerzési információkra ahhoz, hogy a szükséges politikai-katonai döntéseket képes legyen kellö idöben meghozni. Ezért az unió tagállamai megalkották a szükséges dokumentumokat, létrehozták azokat a szervezeteket és mechanizmusokat, amelyek elérhetővé teszik a szövetség számára a nélkülözhetetlen információkat.

Az első ilyen okmány az európai biztonsági stratégia volt, amelyet 2003 decemberében fogadtak el a tagállamok, és azóta az uniós kül- és biztonságpolitika fejlődésének mérföldkövévé vált. Az unió tagállamai első alkalommal állapodtak meg - alapértékeikből kiindulva - közös fenyegetésértékelésről, és tüztek ki egyértelmű célokat az unió biztonsági érdekeinek erősítésére vonatkozóan. Jól tükrözi a megfogalmazott célokat a stratégia címe: Biztonságos Európa egy jobb világban.

Fontos mérföldkő volt az EU Tanácsának határozatával 2010. június 26án létrehozott Európai Külügyi Szolgálat megalapítása. A tanácsi határozat megszabja az Európai Külügyi Szolgálat szervezetének és müködésének rendjét. A szolgálat az unió külügyi és biztonságpolitikai föképviselöjének irányítása alatt müködik. A szolgálat támogatja a főképviselőt a következő megbízatásai teljesítésében:

- az Európai Unió közös kül- és biztonságpolitikájának - beleértve a közös biztonság- és védelempolitikát is - irányítása és kidolgozása;

- a Külügyek Tanácsa elnöki tisztének az ellátása;

- a bizottságban betöltött alelnöki tiszte ellátása külügyi kapcsolatok területén.

Az Európai Külügyi Szolgálat hozzájárul továbbá a tanács fötitkárságának, a bizottságnak és a tagállami diplomáciai szolgálatoknak a munkájához az európai külső tevékenységek koherenciájának fenntartása érdekében.

Végezetül az Európai Külügyi Szolgálat támogatja a bizottságot az unió külső tevékenysége pénzügyi programjainak és eszközeinek kidolgozásában és végrehajtásában. 
Az uniónak nincs saját hírszerző képessége, ezért a hírszerző szervezetek elsősorban a tagállamoktól megkapott hírszerzési információkat dolgozzák fel.

\section{A magán-titkosszolgálatok szerepe}

Az állami nemzetbiztonsági szolgálatok mellett a magán-titkosszolgálatok is megjelentek a rendszerváltozás után Magyarországon. A cégek, amelyekben elsősorban a szolgálatok állományából kivált, vagy eltávolított volt elhárítási és hírszerzési szakemberek dolgoznak - kapcsolataikat felhasználva -, az állami adatbázisokból is információkhoz juthatnak, hogy a megfigyeltekröl felhasználható adatokat gyüjtsenek. Mind gyakoribb, hogy a magán-titkosszolgálatok állami, kormányzati alapfeladatokat is elvállalnak: például személyi védelmet, vagy informatikai rendszerek védelmét, üzemeltetését látják el, természetesen piaci alapon. Sőt a nevesebb magyar magánhírszerzők és -elhárítók - a Magyarországon müködő multinacionális vállalatok megbízására - egyre gyakrabban külföldön is munkát vállalnak.

Napjaikra erős az igény a magánszféra területén, elsősorban az informatikai, gazdasági, üzleti hírszerzésben és elhárításban jártas szaktudásra. Ennek az okai a következök:

- a technikai fejlesztések hatalmas költségigénye, az állami takarékossági intézkedések és a kormányzati túlszabályozás együttes hatása;

- a jogi szabályozás hiányosságai;

- az állami gazdasági és üzleti hírszerzés, elhárítás gyengesége;

- a gazdasági hírszerzés és elhárítás jelentőségének növekedése;

- az úgynevezett „titkosszolgálati eszközök” a szabad piacon olcsón beszerezhetők.

A téma egyik hazai szakértője a magán-titkosszolgálatok jövőbeni szerepe kapcsán így fogalmaz: „, A hazai piacgazdaság erősödésével, a magán-titkosszolgálatok megjelenésével azok tevékenységére, számuk gyarapodására lehet számítani. A hazai biztonsági szférában megjelenö magán-titkosszolgálati vállalkozások egyre gyakrabban és egyre nagyobb mértékben vállalják fel - elsösorban anyagi megfontolásból (ti. az óriási üzlet) - a magánszféra érdekeit szolgáló komplett hírszerzést, elháritást." ${ }_{23}$

23 Lénárt Ferenc: Magán titkosszolgálatok hazai megjelenése és müködése. Hadtudomány, 2008/3. 


\section{A jelen és jövő feladatai}

Napjainkban a hazai és külföldi nemzetbiztonsági szolgálatokat övező botrányoktól hangos a sajtó. Nem mentes ettől a politika és az Országgyülés sem. Sajnos ezek a hírek általában nem a nemzeti értékek és érdekek védelmezőjeként mutatják be ezeket a szervezeteket, éppen ellenkezőleg, azt kívánják bizonyítani, hogy törvénytelen lehallgatásokat, megfigyeléseket és adatgyüjtéseket végeznek. Ezek a beszámolók több okból is káros hatást váltanak ki. Egyrészt félrevezetik a felületes és sokszor egyáltalán nem hiteles információkkal a közvéleményt a szolgálatok munkájával kapcsolatban. Másrészt károsan befolyásolják az állampolgárok véleményét a szolgálatok titkos információgyüjtő tevékenységéröl.

\section{A kiberbiztonság}

A huszonegyedik század legnagyobb próbatétele a kibertér. Erre keresik a választ a nemzetközi szervezetek és a nemzetállamok egyaránt.

A NATO-tagállamok elkészítették a kiberháború kézikönyvét. 2008. május 14-én alapították meg Tallinnban a NATO Kibervédelmi Kiválósági Központját. A központ célja, hogy a NATO-tagállamok és partnereik kibervédelmi kapacitásait erősítse a tapasztalatcsere, oktatás és kutatás-fejlesztés eszközeivel. A központ összegyüjti, értékeli, elemzi és a tagállamok szakirányú szerveivel megosztja mindazt a nemzetközi tapasztalatot és tudást, amely a XXI. század kiberbiztonságának védelméhez szükséges. A központ éves konferencia keretében értékeli a NATO-tagállamok kiberbiztonságát, és rendszeres oktatásokat, továbbképzéseket szervez a kibervédelem és elhárítás témakörében.

Az unió 2013. február 8-án reagált a kihívásra, és kiberbiztonsági tervet jelentett be a nyílt internet, valamint az online szabadság és a lehetőségek védelmére. Az Európai Bizottság - a hálózat- és információbiztonságra vonatkozó bizottsági irányelvjavaslattal egyetemben - egy korábbi ígéretét teljesítve közzétette az Európai Unió kiberbiztonsági stratégiáját. ${ }^{24}$

Hazánkban is felismerte mind a politikai, mind a szakmai vezetés, milyen fontos nemzetbiztonsági érdek az, hogy idejében felkészüljünk a kibertérből érkező fenyegetésekre. Az unió kiberbiztonsági stratégiájához igazodva 2013. március 21-én a Magyar Közlönyben megjelent határozat rögzíti, hogy

24 http://eur-lex.europa.eu/legal-content/HU/TXT/PDF/?uri=CELEX:52013JC0001\&from=HU 
a kormány elfogadja Magyarország nemzeti kiberbiztonsági stratégiáját. Megalakult a Nemzeti Kiberbiztonsági Koordinációs Tanács, és megszületett az állami és önkormányzati szervek elektronikus információbiztonságáról szóló 2013. évi L. törvény.

Mára már mindenki előtt világossá vált, hogy a közeli és távoli jövő nem képzelhető el a kibertérben zajló pozitív és negatív változások nélkül. Csak az a nemzet és szövetség lesz képes a kibertér lehetőségeit hasznosítani, amely kellő időben felismeri ezeket a lehetőségeket, idejében végrehajtja a szükséges fejlesztéseket és létrehozza a hatékony védelmi mechanizmusokat.

\section{Összegzés}

Összegezve a rendszerváltás óta bekövetkezett változásokat láthatjuk, hogy sok minden módosult. Tikos információgyüjtéssel foglalkozó szervezetek szüntek meg (határőrség) és jöttek létre (Terrorelhárítási Központ). Számos a titkos információgyüjtéssel foglalkozó törvény módosult, és újak is születtek. Az alaptörvény elfogadásán túl nagyon sok jogszabály is megváltozott (nyugdíjtörvény, szolgálati törvény stb.), ezek természetesen hatással vannak a nemzetbiztonsági szolgálatok tevékenységére.

A titkos információgyüjtést végző nemzetbiztonsági és bünüldöző szervek szervezetrendszere és jogi szabályozottsága életképes, de lehetne egyszerübb és hatékonyabb. Határozott ellentmondás van az együttmüködést sürgető hazai és nemzetközi veszélyek és a nemzetbiztonsági szervezet széttagoltsága között.

Tény, hogy továbbra is hiányzik egy egységes hazai nemzetbiztonsági stratégia!

A robbanásszerű információtechnológiai fejlődés pedig a technikai fejlesztések terén állította és állítja próbák elé a szolgálatokat. A gazdasági válság elhúzódó hatása nemcsak a nemzetbiztonsági szolgálatok költségvetésére hatott, hat negatívan, hanem a hivatásos és közalkalmazotti állomány megélhetését is nagyban nehezítette, nehezíti. Természetesen a nemzetbiztonsági szolgálatok technikai fejlődésének, szervezeti fejlesztésének, képzési, továbbképzési rendszerének, a tudományos és kutató munkának mindig igazodnia kell a kormányzati elvárásokhoz, és figyelembe kell vennie a tudomány és technika vívmányait. 